\title{
Synthesis and Spectroscopic Analysis of Piperine- and Piperlongumine-Inspired Natural Product Scaffolds and Their Molecular Docking with IL-1 $\beta$ and NF-KB Proteins
}

\author{
Gabriel Zazeri ${ }^{1,2}$, Ana Paula R. Povinelli ${ }^{1,2}{ }^{-}$, Cécile S. Le Duff ${ }^{3}{ }^{\circledR}$, Bridget Tang ${ }^{3}$, \\ Marinonio L. Cornelio ${ }^{1, *(\mathbb{D}) \text { and Alan M. Jones }}{ }^{2, *(D)}$ \\ 1 Departamento de Física-IBILCE, Rua Cristovão Colombo, 2265 CEP 15054-000 São José do Rio \\ Preto-São Paulo, Brazil; gabriel.zazeri@unesp.br (G.Z.); ana.povinelli@unesp.br (A.P.R.P.) \\ 2 School of Pharmacy, University of Birmingham, Edgbaston B15 2TT, UK \\ 3 School of Chemistry, University of Birmingham, Edgbaston B15 2TT, UK; C.S.LeDuff@bham.ac.uk (C.S.L.D.); \\ B.Tang@bham.ac.uk (B.T.) \\ * Correspondence: m.cornelio@unesp.br (M.L.C.); a.m.jones.2@bham.ac.uk (A.M.J.)
}

Academic Editor: Maged Henary

Received: 19 May 2020; Accepted: 16 June 2020; Published: 19 June 2020

\begin{abstract}
Inspired by the remarkable bioactivities exhibited by the natural products, piperine and piperlongumine, we synthesised eight natural product-inspired analogues to further investigate their structures. For the first time, we confirmed the structure of the key cyclised dihydropyrazolecarbothioamide piperine analogues including the use of two-dimensional (2D) ${ }^{15} \mathrm{~N}$-based spectroscopy nuclear magnetic resonance (NMR) spectroscopy. Prior investigations demonstrated promising results from these scaffolds for the inhibition of inflammatory response via downregulation of the IL- $1 \beta$ and NF- $\mathrm{kB}$ pathway. However, the molecular interaction of these molecules with their protein targets remains unknown. Ab initio calculations revealed the electronic density function map of the molecules, showing the effects of structural modification in the electronic structure. Finally, molecular interactions between the synthesized molecules and the proteins IL-1 $\beta$ and NF- $\mathrm{KB}$ were achieved. Docking results showed that all the analogues interact in the DNA binding site of NF- $\mathrm{kB}$ with higher affinity compared to the natural products and, with the exception of 9a and $9 b$, have higher affinity than the natural products for the binding site of IL- $1 \beta$. Specificity for the molecular recognition of $\mathbf{3 a}, \mathbf{3} \mathbf{c}$ and $\mathbf{9 b}$ with IL-1 $\beta$ through cation $-\pi$ interactions was determined. These results revealed $\mathbf{3 a}, \mathbf{3} \mathbf{c}, \mathbf{4 a}, \mathbf{4} \mathbf{c}$ and $\mathbf{1 0}$ as the most promising molecules to be evaluated as IL-1 $\beta$ and NF- $\mathrm{kB}$ inhibitors.
\end{abstract}

Keywords: molecular docking; piperine; piperlongumine

\section{Introduction}

Nature is a creative machine for the design of bioactive molecules with the potential to become efficient drugs for the treatment of several diseases. In recent decades, such creative scaffolds have driven the design of new molecules with pharmacological potential, including the concept of diversity-oriented synthesis (DOS) [1,2]. In recent years, both piperine and piperlongumine have been explored because of their wide spectrum of biological activity [3-8].

Piperine is an alkaloid found in piper species such as Piper nigrum (black pepper) and Piper longum (long pepper). Piperine is not only used as a seasoning but also in various preparations of traditional medicine, including the oldest medical science, practiced in India since ancient times (Ayurveda) [9]. Piperine has been widely studied by the scientific community, because of its anti-inflammatory, 
anti-carcinogenic, immunomodulatory and hepatoprotective activities [3]. As an anti-inflammatory, piperine acts through the inhibition of IL-1 $\beta$ and NF-KB inflammation pathway, leading to the downregulation of pro-inflammatory proteins, such as iNOS and COX-2 [10-12].

Piperine-inspired molecules investigated in the present work have had their anti-inflammatory and anti-carcinogenic activity previously studied by Mathew et al. [13,14], with promising results. In particular, $\mathbf{4 a}$ had a comparable anti-inflammatory effect to Diclofenac. Furthermore, $\mathbf{3 c}$ and $\mathbf{4 c}$ showed inhibitory effects on the HCT116 colon cancer cell line. However, their interactions with the IL-1 $\beta$ and NF- $\kappa B$ pathways have not been investigated.

Piperlongumine (PPL), is an alkaloid isolated from long pepper that is widely used in Indian traditional medicine [15]. The biological activities of PPL and its analogues include anti-inflammatory, anti-carcinogenic and anti-atherosclerotic activities, among others [6-8,16]. Similar to piperine, studies indicated that anti-inflammatory and anti-carcinogenic activities of PPL are a consequence of the inhibition of the NF- $\mathrm{kB}$ pathway [17-20].

PPL has been shown to bind to the unit p65 of NF- $\mathrm{kB}$, inhibiting NF- $\mathrm{kB} / \mathrm{DNA}$ binding activity and blocking the transcription of cytokines and other pro-inflammatory proteins [18].

Despite the investigations reported in the literature that show promising results of these natural-product-inspired analogues in the inhibition of inflammatory response via the downregulation of IL-1 $\beta$ and NF- $\mathrm{kB}$ pathway, the molecular interaction of these molecules with the protein targets are unknown.

Herein, we explored the binding environment of the synthesised analogues in NF- $\mathrm{kB}$ and IL-1 $\beta$ using molecular docking. For piperine-inspired molecules, we investigated the effect caused by the substitution of the piperidine for an aromatic ring in the piperine scaffold (3a), a nitroarene group (3b) and an aminoarene group (3c). We investigated the effect of the cyclisation of the piperine scaffold to form a dihydropyrazolecarbothioamide moiety (4a and 4c). For PPL-inspired molecules, we investigated the effects of removing a Michael acceptor (9a), the conversion of a lactam to a ketone (10) and the influence of methoxy groups $(9 \mathbf{b})$.

We present an adapted synthesis of piperine- and PPL-inspired molecules including data from $2 \mathrm{D}{ }^{1} \mathrm{H}_{-}{ }^{15} \mathrm{~N}$ HSQC and HMBC spectra, computational characterization of the electronic structure of the analogues using $a b$ initio calculations and molecular docking of the confirmed structures with the proteins IL-1 $\beta$ and NF- $\kappa$ B.

\section{Results and Discussion}

\subsection{Spectroscopic Characterization of Natural Product Inspired Analogues}

The synthesis of the piperine-inspired analogues began with a $\mathrm{MnO}_{2}$-mediated oxidation of piperonyl alcohol to the corresponding aldehyde with a 97\% yield (Scheme 1). Claisen-Schmidt condensation of $\mathbf{2}$ with a variety of acetophenones afforded 3a-3c in excellent yields (80-90\%) after crystallisation. The initial synthetic route to $4 \mathrm{c}$ required the synthesis of the nitro derivative ( $3 b)$ followed by cyclisation with thiosemicarbazide and reduction, as the free amine may undergo unwanted side reactions during the cyclisation step. Unfortunately, all attempts to react $\mathbf{3 b}$ with thiosemicarbazide resulted in recovered starting material. However, for the parent unsubstituted compound (3a) a cyclised compound (4a) was formed with $60 \%$ yield. Pleasingly, the unprotected amine containing molecule $3 \mathrm{c}$ was smoothly converted to the cyclised molecule $4 \mathrm{c}$ with $60 \%$ yield, mitigating the need to pursue $3 \mathbf{b}$ further. 


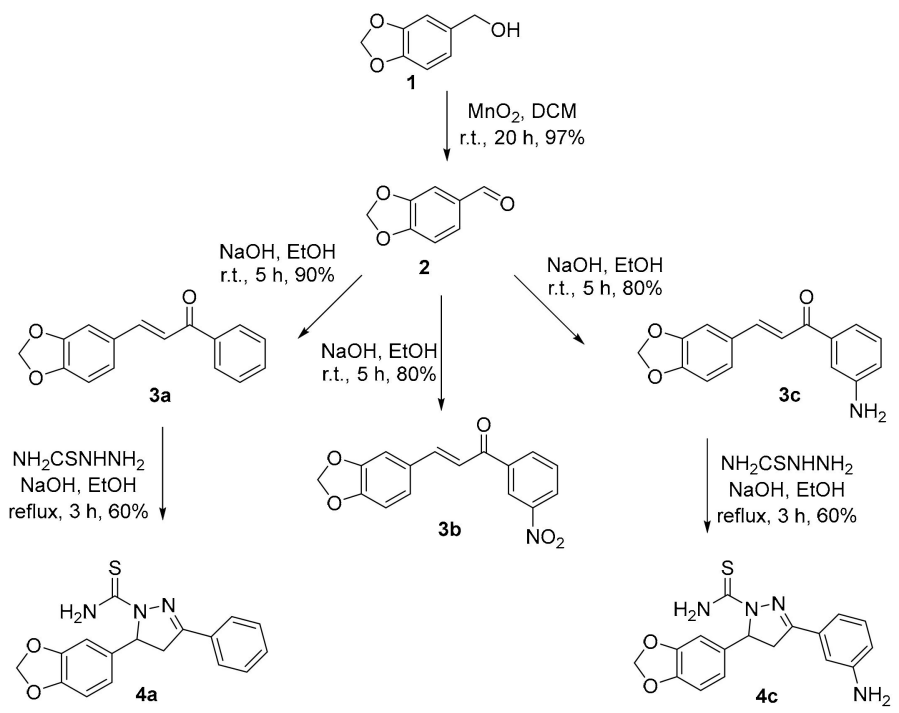

Scheme 1. Synthesis of piperine-inspired molecules.

The syntheses of piperine analogues have been reported by Mathew et al. [13] but with limited spectroscopic characterization ( ${ }^{1} \mathrm{H}$ NMR and IR spectroscopy) of molecules of type 4 . We therefore performed re-synthesis prior to the computational study to confirm the connectivity of the new ring system. There is a potential for either a five-membered product (4a), or a seven-membered ring system (5) to form (Scheme 2). Selected instructive $2 \mathrm{D}^{1} \mathrm{H}_{-}{ }^{13} \mathrm{C}$ HMBC and ${ }^{1} \mathrm{H}_{-}-{ }^{15} \mathrm{~N}$ HMBC NMR spectra connectivities are shown in Scheme 2, along with the ${ }^{15} \mathrm{~N}$ NMR chemical shifts. Critically, the results showed the correct connectivity for a five-membered dihydropyrazolecarbothioamide system product (4a not 5). 4a was found to slowly degrade upon standing in $\mathrm{CDCl}_{3}$ at room temperature for an extended period of time.
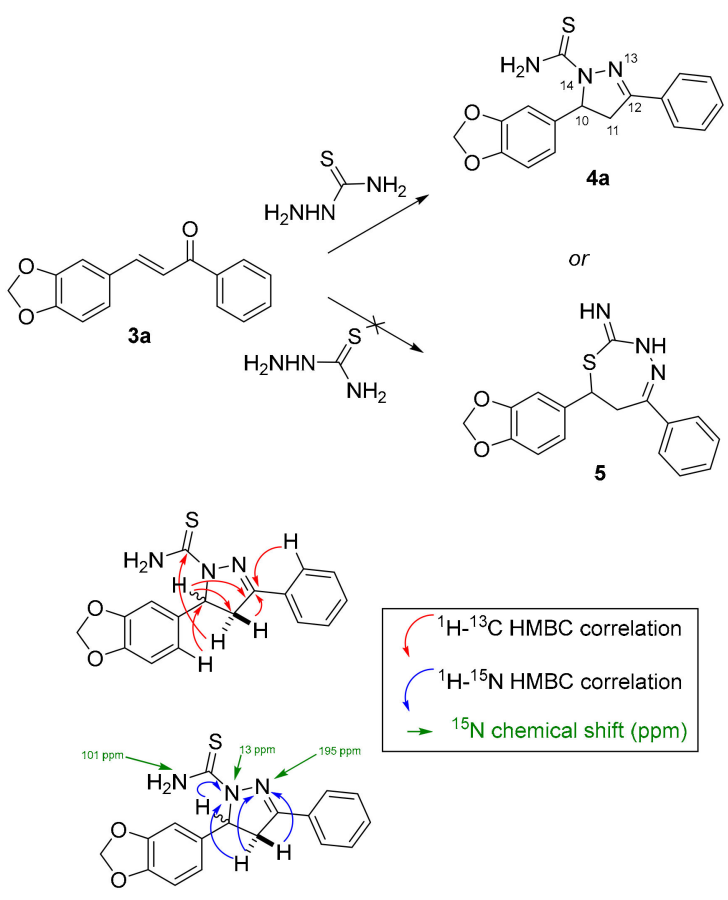

Scheme 2. Two potential cyclisation outcomes upon 3a and the selected instructive NMR correlations for $4 \mathbf{a}$ in the $2 \mathrm{D}^{1} \mathrm{H}_{-}{ }^{13} \mathrm{C} \mathrm{HMBC}$ and $2 \mathrm{D}^{1} \mathrm{H}_{-}{ }^{15} \mathrm{~N}$ HMBC spectra. 
The synthesis of the PPL-inspired analogues (Scheme 3) used a one-pot Doebner-modified Knoevenagel condensation and concomitant decarboxylation, to prepare the key acrylic acids $(7 \mathbf{a}, \mathbf{b})$ from the appropriate benzaldehydes. Reaction of the acrylic acids with thionyl chloride under Vilsmeier-Haack conditions gave the short-lived vinylogous acyl chlorides $(\mathbf{8} \mathbf{a}, \mathbf{b})$ which were reacted with either sodium 2-oxopiperidin-1-ide (derived from $\delta$-valerolactam) or with lithium cyclohex-1-en-1-olate (derived from cyclohexanone), to afford the final products $\mathbf{9 a}, \mathbf{b}$ and $\mathbf{1 0}$ with modest isolated yields.

Although 10a has been reported in the literature, we identified a previously unobserved ${ }^{1} \mathrm{H} N M R$ spectroscopic signal at $15.76 \mathrm{ppm}$ (Supplementary Materials), indicative of an intramolecular hydrogen bond occurring through tautomerization to give the stabilized structure, $\mathbf{1 0 .}$<smiles>COc1cc(C=O)cc(OC)c1OC</smiles>

$6 a$<smiles>COc1ccc(C=O)cc1</smiles>

$6 b$

$85 \%\left\lfloor\begin{array}{c}\text { malonic acid, pyridine, } \\ \text { piperidine, } 95{ }^{\circ} \mathrm{C}, 4 \mathrm{~h}\end{array} \mid 98 \%\right.$<smiles>COc1cc(/C=C/C(=O)O)cc(OC)c1OC</smiles><smiles>COc1ccc(/C=C/C(=O)O)cc1</smiles>

$7 a$

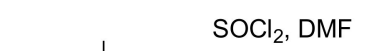
\begin{tabular}{cc|c}
$\begin{array}{c}\text { Cyclohex-2-enone } \\
\text { LDA, THF } \\
-78{ }^{\circ} \mathrm{C}-\text { r.t. } 2 \mathrm{~h}\end{array}$ & $99 \%$ & $\begin{array}{c}\mathrm{SOCl}_{2} \text {, DMF } \\
\mathrm{DCM}, \text { reflux, } 5 \mathrm{~h}\end{array}$
\end{tabular}<smiles>COc1cc(/C=C/C2=C3CCC=CC3OPO2)cc(OC)c1OC</smiles>

$-78^{\circ} \mathrm{C}$ - r.t. $2 \mathrm{~h}$<smiles>COc1cc(/C=C/C(=O)Cl)cc(OC)c1OC</smiles><smiles>COc1ccc(/C=C/C(=O)Cl)cc1</smiles>

$8 a$

$8 b$<smiles>COc1cc(/C=C/C(=O)C2CCC=CC2=O)cc(OC)c1OC</smiles><smiles>[134Co]</smiles>
$\delta$-valerolactam $\mathrm{NaH}$ THF $0{ }^{\circ} \mathrm{C}-$ r.t. $2 \mathrm{~h}$<smiles>COc1cc(/C=C/C(=O)N2CCCCC2=O)cc(OC)c1OC</smiles>

$9 a$<smiles>COc1ccc(/C=C/C(=O)N2CCCCC2=O)cc1</smiles>

$9 b$

Scheme 3. Synthesis of piperlongumine-inspired molecules. 


\subsection{Electronic Structures of Piperine and PPL-Inspired Molecules}

$A b$ initio calculations were performed to obtain the structural parameterisation to be used in the molecular docking calculations. In addition, these calculations provided information about the electronic structure that contributed to the characterisation of the compounds.

Figure 1 shows the structures resulting from $a b$ initio calculations of their respective map of electrostatic potential (MEP). 3a,b,c presented a planar structure due to the high number of conjugated double bonds. A similar result was found for piperine previously [21]. 3a,b,c have the most negative charge density around oxygen atoms, while the most positive charge densities are concentrated on the extremities of the structures with the intermediate region being more neutral. As a special case, the nitro group in $3 b$ relocated the negative charges from the aromatic ring to the oxygen atoms, consequently the aromatic ring of $\mathbf{3 b}$ became more positive when compared to $\mathbf{3 a} \mathbf{a} \mathbf{c}$ and may explain its unreactivity to thiosemicarbazide. This relocation of negative charges caused $3 \mathbf{b}$ to have high affinity for a microenvironment mainly composed by polar amino acids, which differs from 3a,c, which preferred less polar microenvironments (see molecular docking). The MEP of 4a,c indicated that the negative density charge was concentrated around the oxygen, nitrogen and the sulfur atoms, while the positive density charge was concentrated on the dihydropyrazole and 1,3-benzodioxole rings, with the neutral region being the aromatic ring.
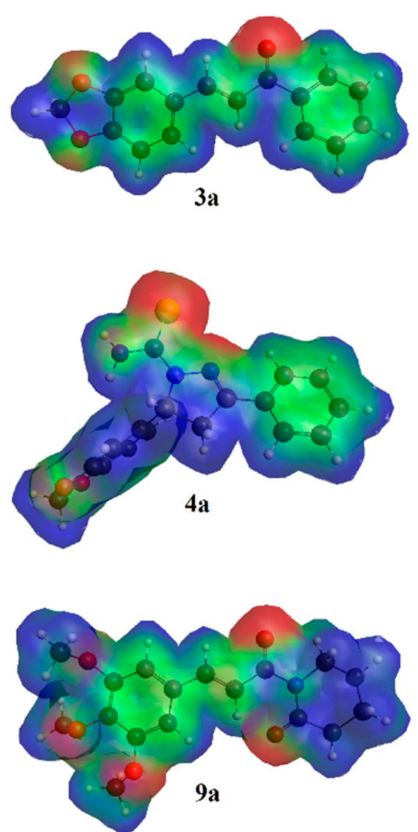
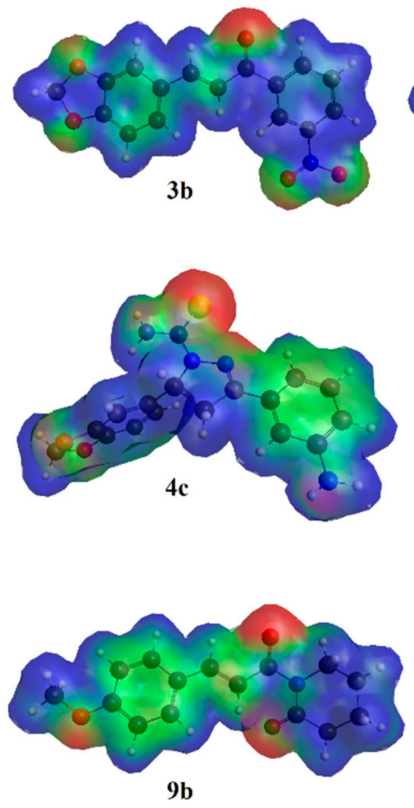
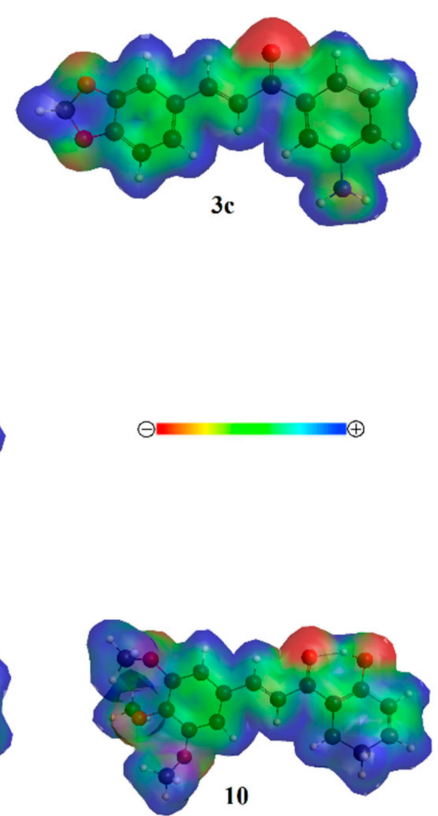

Figure 1. Map of electronic potential (MEP) of piperine and PPL-inspired molecules, where the scale is from negative density charge (represented by red) to positive density charge (represented by blue).

A minimal puckering of the five-membered ring system of 4 a modelled in $\mathrm{CDCl}_{3}$ revealed a maximal torsional angle of $+4.8^{\circ}$ around $\mathrm{C}(10)-\mathrm{N}(14)-\mathrm{N}(13)-\mathrm{C}(12)$ and a minimal torsional angle of $-3.0^{\circ}$ across the ring system. This deviation away from planarity may explain the low $15 \mathrm{ppm}{ }^{15} \mathrm{~N}$ NMR signal observed in this ring system.

9a, 10 and 9b presented a planar structure, except for methoxy groups (see Figure S39, Supplementary Materials). ${ }^{1} \mathrm{H}$ NMR of $\mathbf{1 0}$ (Figure S38, Supplementary Materials) showed a resonance peak at $15.76 \mathrm{ppm}$, associated with the hydroxyl from cyclohexanone forming an intramolecular hydrogen bond with the adjacent carbonyl oxygen; consequently, this hydrogen is not exchangeable and the signal is observed in the ${ }^{1} \mathrm{H}$ NMR spectrum. According to ab initio calculations for 10, the intramolecular hydrogen bond length is $1.55 \AA$. The planarity of the three structures are quite similar to the characteristics found in PPL [22]. According to MEP, the three structures presented a 
negative density charge concentrated around oxygen atoms, while the positive density distributed on the extremity of the molecule and the aromatic ring is a neutral part of the molecules. The negative density charge concentrated on the atoms identified plays a crucial role in the interaction of $\mathbf{1 0}$ with $\mathrm{NF}-\mathrm{kB}$, as the binding site is positively charged.

\subsection{Molecular Docking}

According to molecular docking results with IL-1 $\beta$ (Figure 2), piperine and analogues 3a, 4a, 3c and $4 \mathrm{c}$ bound to the same binding site with the binding energy scores of $-6.08,-6.04,-7.18,-6.25$ and $-7.22 \mathrm{kcal} / \mathrm{mol}$, respectively.
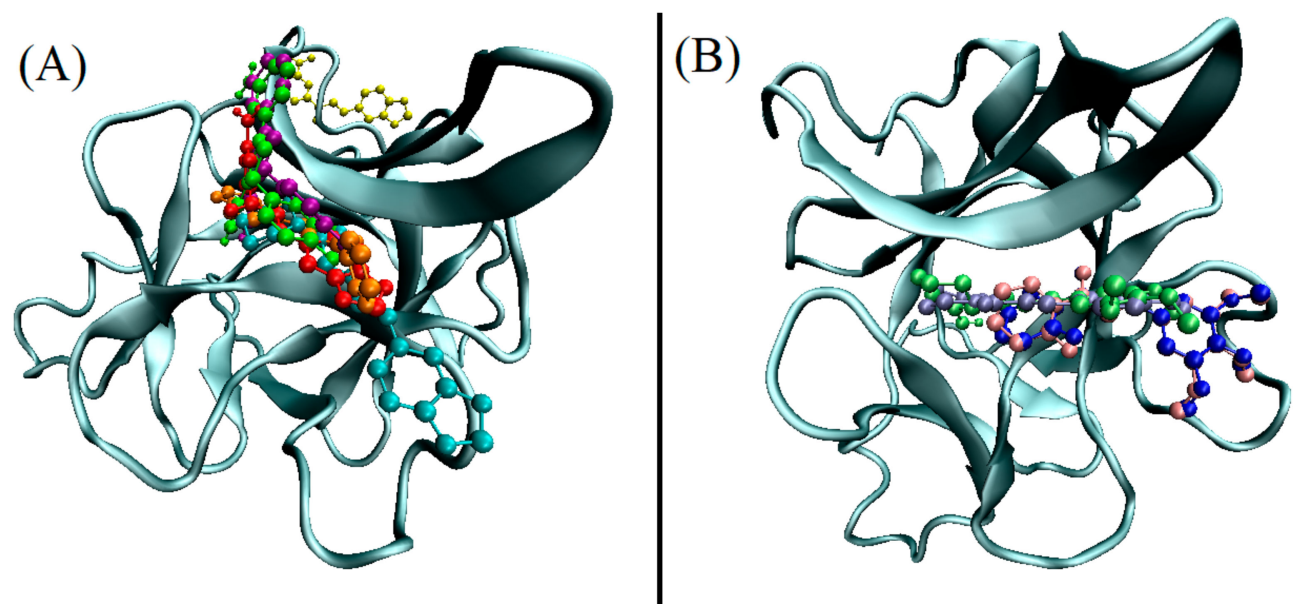

Figure 2. IL-1 $\beta$ (iceblue) binding environments to (A) piperine and analogues (Piperine-cyan, 3a-orange, 4a-purple, 3b-yellow, 3c-red, 4c-green). (B) PPL and analogues (PPL-blue, 9a-pink, 10-lime, 9b-iceblue).

Figure 3 and Table 1 show the amino acids that compose the microenvironment of each molecule with IL-1 $\beta$. According to the docking results $4 a, 3 c$ and $4 c$ had a more negative binding energy than piperine; having a higher affinity for this environment when compared to piperine (Table 2). Most of the amino acids that composed the binding site are non-polar, with limited neutral and charged polar amino acids participating. The higher affinity of the analogues for the binding site revealed that the addition of an aromatic ring, and consequently the new electronic distribution, contributed to the increase in affinity. Moreover, the aromatic rings of $3 a, c$ exhibited cation $-\pi$ interactions with the protonated amine group of Lys77 amino acid (see Supplementary Materials), which contributed to the high negative binding energy of these analogues to the protein. The cation $-\pi$ interaction is caused by the molecular electron delocalization, reinforcing the importance of the increase in electron delocalization for the affinity at the IL-1 $\beta$ binding site. 

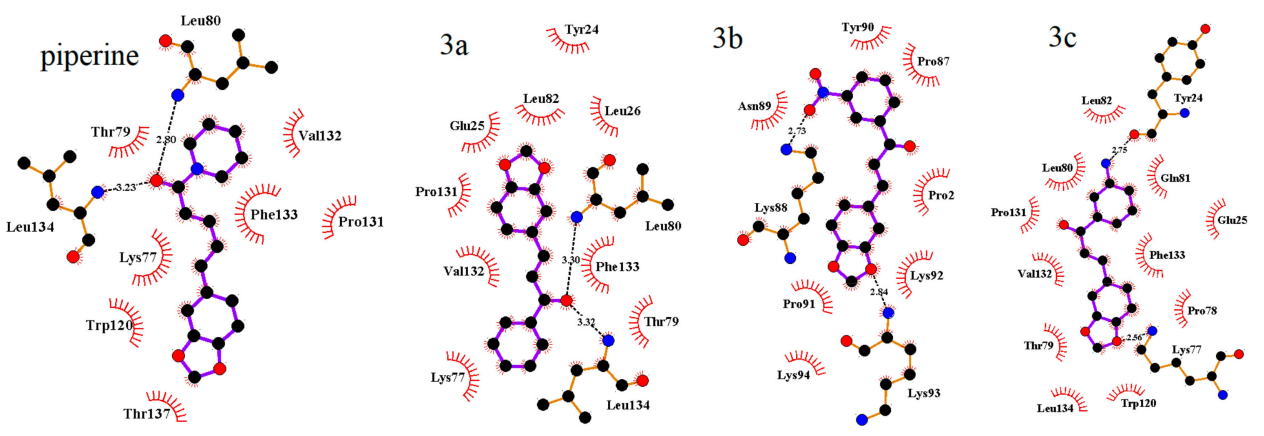

$4 a$

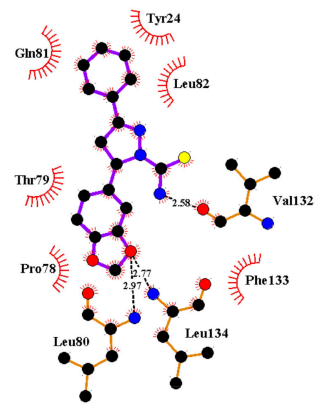

$9 \mathrm{a}$

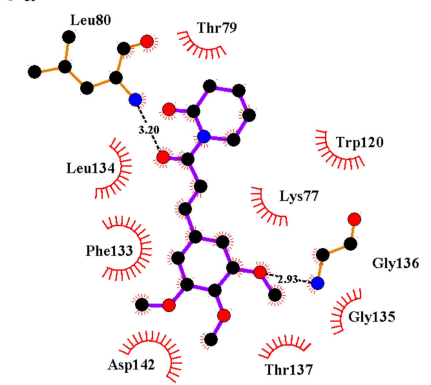

$4 c$

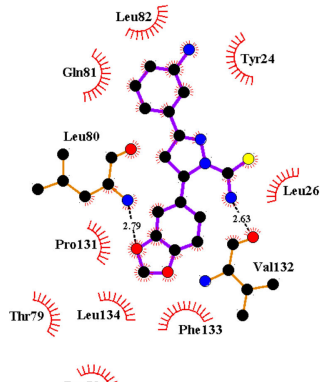

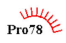

$9 b$

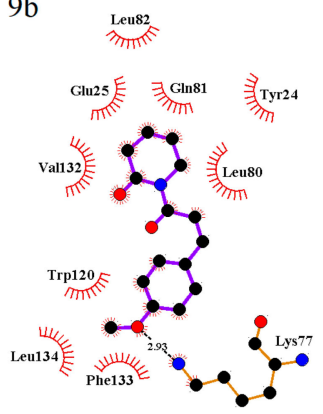

PPL

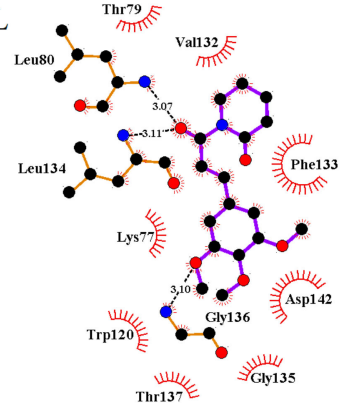

10

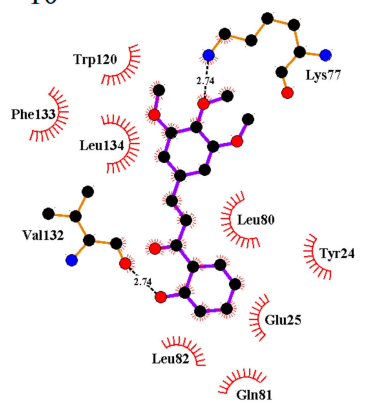

Figure 3. IL-1 $\beta$ binding microenvironments details for piperine and PPL analogues visualized with LigPlot.

Table 1. Amino acids that compose the microenvironment of the complex IL- $1 \beta /$ piperine and PPL analogues, obtained by molecular docking.

\begin{tabular}{|c|c|c|c|c|}
\hline \multirow[b]{2}{*}{ Molecule } & \multicolumn{4}{|c|}{ Amino Acids } \\
\hline & Non-Polar & $\begin{array}{l}\text { Positively } \\
\text { Charged }\end{array}$ & $\begin{array}{l}\text { Negatively } \\
\text { Charged }\end{array}$ & Polar \\
\hline Piperine & $\begin{array}{l}\text { Leu80, Leu134, Val32, } \\
\text { Phe133, Pro131, Trp120 }\end{array}$ & Lys77 & - & Thr137, Thr79 \\
\hline $3 a$ & $\begin{array}{l}\text { Leu82, Leu26, Leu80, Leu134, } \\
\text { Phe133, Val132 and Pro131 }\end{array}$ & Lys77 & Glu25 & Thr79 \\
\hline $4 a$ & $\begin{array}{l}\text { Leu80,Leu82, Leu134,Val132, } \\
\text { Phe133, Pro78 }\end{array}$ & - & - & Thr79, Gln81, Tyr24 \\
\hline $3 b$ & Pro2, Pro87, Pro91 & $\begin{array}{l}\text { Lys88, Lys92, } \\
\text { Lys93, Lys94 }\end{array}$ & - & Asn89, Tyr90, \\
\hline $3 c$ & $\begin{array}{l}\text { Leu80, Leu82, Leu134, Phe133, } \\
\text { Pro78, Trp120, Val132, Pro131 }\end{array}$ & Lys77 & Glu25 & Tyr24, Gln81 \\
\hline $4 c$ & $\begin{array}{l}\text { Leu26, Val132, Phe133, Pro78, } \\
\text { Leu134, Leu82 Pro131, Leu80, }\end{array}$ & - & - & Gln81, Tyr24, Thr79 \\
\hline
\end{tabular}


Table 1. Cont.

\begin{tabular}{ccccc}
\hline \multirow{2}{*}{ Molecule } & \multicolumn{4}{c}{ Amino Acids } \\
\cline { 2 - 5 } & Non-Polar & $\begin{array}{c}\text { Positively } \\
\text { Charged }\end{array}$ & $\begin{array}{c}\text { Negatively } \\
\text { Charged }\end{array}$ & Polar \\
\hline PPL & $\begin{array}{c}\text { Val132, Phe133, Gly135, Gly136, } \\
\text { Trp120, Leu134, Leu80 }\end{array}$ & Lys77 & Asp142 & Thr79, Thr137 \\
\hline $\mathbf{9 a}$ & $\begin{array}{c}\text { Leu80, Trp120, Gly136, Gly135, } \\
\text { Phe133, Leu134 }\end{array}$ & Lys77 & Asp142 & Thr79, Thr137 \\
\hline $\mathbf{1 0}$ & $\begin{array}{r}\text { Trp120, Leu80, Leu82, Val32, } \\
\text { Leu134, Phe133 }\end{array}$ & Lys77 & Glu25 & Tyr24, Gln81 \\
\hline $\mathbf{9 b}$ & $\begin{array}{c}\text { Leu82, Leu80, Phe133, Leu134, } \\
\text { Trp120, Val132 }\end{array}$ & Lys77 & Glu25, & Gln81, Tyr24 \\
\hline
\end{tabular}

As a consequence of the new structural properties, $4 \mathbf{a}$ and $4 \mathbf{c}$ presented the best affinities to this binding site. Analogue $3 \mathbf{b}$ bound with a binding energy of $-7.44 \mathrm{kcal} / \mathrm{mol}$ to an orthosteric binding site, where the majority of amino acids are positive and neutral polar amino acids. The differences between $\mathbf{3 a}, \mathbf{c}$ and $\mathbf{3 b}$ are due to the aromatic ring substitution, the nitro group in $\mathbf{3 b}$ drove the interaction to a less hydrophobic environment, differently from the amino group (3c).

The binding site found by molecular docking for PPL and analogues was the same as the piperine binding site. Table 2 shows that PPL, $\mathbf{9 a}, \mathbf{1 0}$ and $\mathbf{9 b}$ had binding scores of $-5.83,-5.38,-6.19$ and $-5.62 \mathrm{kcal} / \mathrm{mol}$, respectively. In the case of PPL analogues, 10 presented the most negative binding energy and highest affinity for the binding site. The results showed that the removal of two methoxy groups ( $9 \mathbf{b})$ limited the possibility of performing multiple hydrogen bonds. Furthermore, $\mathbf{9 b}$ exhibited a cation $-\pi$ interaction with the protonated amine of Lys77 (see Supplementary Materials), which contributed to the negative binding energy. Docking results also showed that the removal of the double bond in the cyclic ring (9a) resulted in higher binding energy (less negative) than the other molecules, which reinforced the importance of electron delocalization in the binding affinity.

Table 2. Binding energy scores obtained for the proteins IL-1 $\beta$ and NF- $k B$ with Piperine, PPL and analogues.

\begin{tabular}{ccc}
\hline Molecules & Energy Score kcal/mol (IL-1B) & Energy Score kcal/mol (NF-KB) \\
\hline Piperine & -6.08 & -6.08 \\
3a & -6.04 & -6.53 \\
3b & -7.44 & -6.24 \\
3c & -6.25 & -6.07 \\
4a & -7.18 & -6.64 \\
4c & -7.22 & -6.4 \\
PPL & -5.83 & -5.36 \\
9a & -5.38 & -5.85 \\
10 & -6.19 & -5.72 \\
9b & -5.62 & -5.87 \\
\hline
\end{tabular}

In the case of the interaction with NF- $\mathrm{kB}$, all the piperine and piperlongumine analogues, with the exception of $3 \mathbf{c}$, presented a more negative binding energy (Table 2) than the natural products. Piperine, $\mathbf{4 a}, \mathbf{3 b}, \mathbf{3 c}, \mathbf{4 c}, \mathrm{PPL}, \mathbf{9 a}, \mathbf{1 0}$ and $\mathbf{9 b}$ all bound to the DNA binding site of NF-KB (Figure 4) [23]. Table 3 and Figure 5 show that the microenvironments of interaction of these molecules in NF-kB present a significant number of non-polar amino acids (except for $\mathbf{3 b}$ ), similar to the IL-1 $\beta$ binding site. However, in the case of the NF- $\mathrm{kB}$ binding site, there is also a greater number of positively charged amino acids. The interaction of the analogues with the positively charged amino acids may play an important role in the inhibition of the interaction NF- $\mathrm{KB}(\mathrm{p} 65)$-DNA, as positively charged amino acids (including Lys122 and Lys123) stabilize the NF- $\mathrm{kB}(\mathrm{p} 65)$-DNA complex via interaction with the negatively charged phosphates groups of the DNA [24]. 

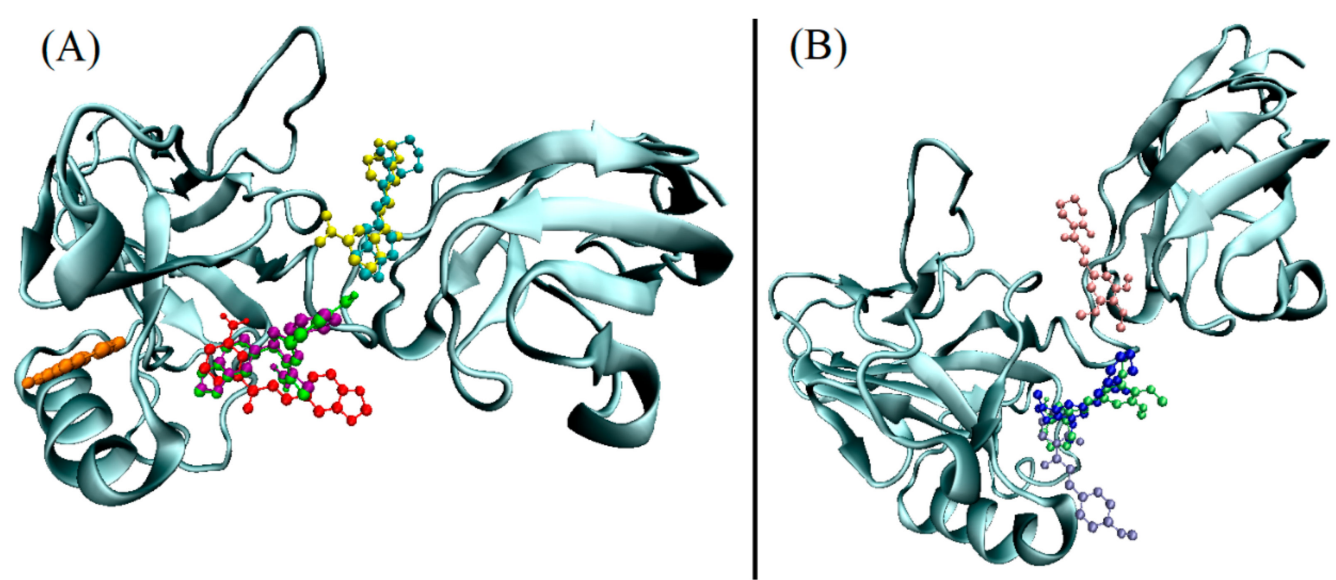

Figure 4. NF- $\mathrm{kB}$ (iceblue) binding environments to (A) Piperine and analogues (Piperine-cyan, 3a-orange, 4a-purple, 3b-yellow, 3c-red, 4c-green). (B) PPL and analogues (PPL-blue, 9a-pink, 10-lime, 9b-iceblue).

Table 3. Amino acids that compose the microenvironment of the complex NF-kB/piperine and PPL analogues, obtained by molecular docking.

\begin{tabular}{|c|c|c|c|c|}
\hline \multirow[b]{2}{*}{ Molecules } & \multicolumn{4}{|c|}{ Amino Acids } \\
\hline & Non-Polar & $\begin{array}{l}\text { Positively } \\
\text { Charged }\end{array}$ & $\begin{array}{l}\text { Negatively } \\
\text { Charged }\end{array}$ & Polar \\
\hline Piperine & Ala192, Leu194 & $\begin{array}{l}\text { Lys195, Arg187, } \\
\text { Lys218 }\end{array}$ & $\begin{array}{l}\text { Glu193, Glu282, } \\
\text { Asp217 }\end{array}$ & Asn186, \\
\hline $3 a$ & $\begin{array}{l}\text { Val121, Ala129, } \\
\text { Cys38, Cys120 }\end{array}$ & $\begin{array}{l}\text { Lys37, Lys122, } \\
\text { Arg133 }\end{array}$ & Glu89 & Tyr36, Gln132 \\
\hline $4 a$ & $\begin{array}{c}\text { Ala188, Cys120, Leu154, } \\
\text { Val121, Pro189 }\end{array}$ & $\begin{array}{l}\text { Arg187, Lys122, } \\
\text { Lys123, His88 }\end{array}$ & Asp185 & $\begin{array}{l}\text { Tyr36, His88, } \\
\text { Asn155 }\end{array}$ \\
\hline $3 b$ & Ala192 & $\begin{array}{l}\text { Arg33, Arg187, } \\
\text { Lys195, Lys218 }\end{array}$ & Asp217, Glu193, & Asn186, \\
\hline $3 c$ & $\begin{array}{l}\text { Cys120, Leu154, Val121, } \\
\text { Pro189, Ala188, Phe34 }\end{array}$ & His88, Lys123 & - & $\begin{array}{c}\text { His88, Tyr36, } \\
\text { Asn155, Gln220, } \\
\text { Asn190, Asp185 }\end{array}$ \\
\hline $4 c$ & $\begin{array}{l}\text { Pro189, Leu154, His88, } \\
\text { Val121, Cys120, Ala188 }\end{array}$ & $\begin{array}{l}\text { Lys123, Lys122, } \\
\text { Arg187 }\end{array}$ & - & $\begin{array}{l}\text { Asp185, Tyr36, } \\
\text { His88, Asn155, }\end{array}$ \\
\hline PPL & $\begin{array}{c}\text { Cys120, Phe34, Leu154, } \\
\text { Ala188, Pro189 }\end{array}$ & $\begin{array}{c}\text { Lys218, Arg187, } \\
\text { His88 }\end{array}$ & Asp185, & Tyr36, Asn155 \\
\hline $9 a$ & Ala188, Ala192, Pro189 & $\begin{array}{l}\text { Lys218, Lys195, } \\
\text { Arg33, Arg187, } \\
\text { Lys194 }\end{array}$ & Asp217, Glu193 & Asn186, \\
\hline 10 & $\begin{array}{l}\text { Ala188, Phe34, Cys120, } \\
\text { Leu154, Val121, Pro189 }\end{array}$ & $\begin{array}{l}\text { Lys218, Arg187, } \\
\text { His } 88\end{array}$ & Asp185 & Asn155, His88 \\
\hline $9 b$ & Leu154, Cys120, Val121, & $\begin{array}{l}\text { His88, Lys123, } \\
\text { Lys122, Arg124 }\end{array}$ & Asp185 & Tyr36, Asn155 \\
\hline
\end{tabular}



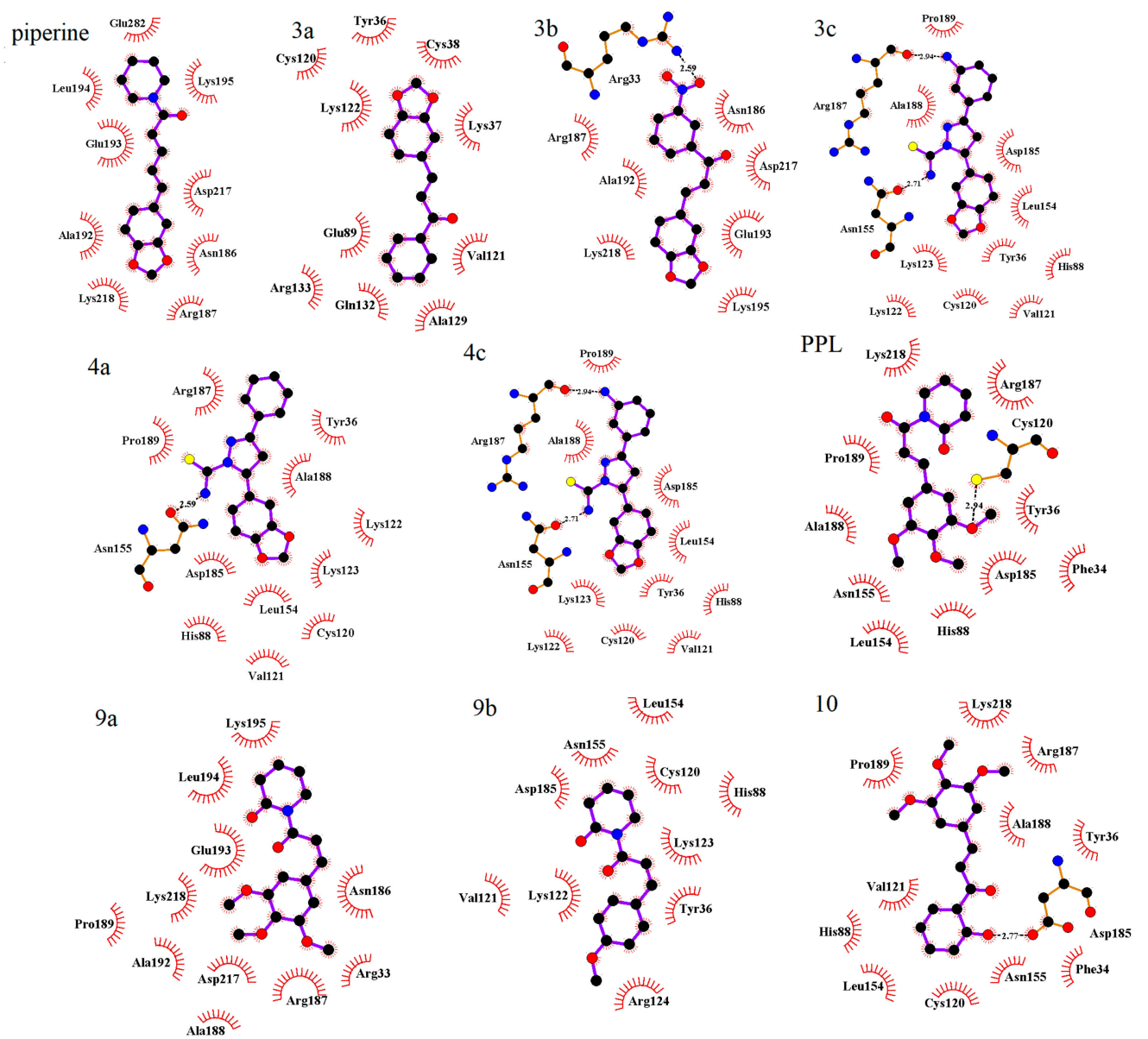

Figure 5. NF- $\mathrm{kB}$ binding microenvironments details for piperine and PPL analogues visualized with LigPlot.

Chen Y.Q. et al. [24] showed that the phenol ring of Tyr36 is anchored by a hydrogen bond to the phosphate backbone of DNA and makes van der Waals contacts with the methyl group of thymine at positions 1 and 2 of DNA, which makes $3 \mathbf{a}, \mathbf{4 a}, \mathbf{3 c}, \mathbf{4} \mathbf{c}$ and $\mathbf{9 b}$ good candidates to inhibit this interaction. Our molecular docking results revealed that Tyr36 was part of the binding microenvironment of these analogues and performed non-specific interactions.

Moreover, the side chain of Arg187 performs a hydrogen bond with the oxygen atom of thymine, and the side chain of Arg33 performs hydrogen bonds to oxygen and nitrogen atoms of guanine [24]. In this case, our molecular docking results showed that $3 b$ and $4 c$ perform hydrogen bonds with Arg33 and Arg187, indicating promising results for these compounds as inhibitors of this interaction between the arginine and DNA bases thymine and guanine.

It has been shown that the specificity of the interaction p65-DNA is likely due to the interactions between the G-C base pair and the side chains of Arg33 and Glu39 [24]. The amino acid Arg33, highlighted as being fundamental to DNA molecular recognition, is present in the microenvironments of the analogues $3 \mathbf{b}$ and $\mathbf{9 a}$ and performs a hydrogen bond with $\mathbf{3 b}$, which indicates that these analogues may shield the DNA recognition.

\section{Materials and Methods}

All reagents and solvents were obtained commercially from Sigma-Aldrich or Fischer Scientific and were used as supplied, with the exception of tetrahydrofuran (THF) and dichloromethane (DCM) which were treated with $3.0 \AA$ molecular sieves $(20 \% \mathrm{~m} / \mathrm{v})$ for a minimum of $48 \mathrm{~h}$ prior to use [25]. The progress of the syntheses was monitored by thin-layer chromatography (TLC). General procedures 
for the syntheses of PPL-inspired molecules were adapted from Sun Lan-Di et al. [18] For the syntheses of piperine-inspired molecules, the procedures were adapted from Mathew, A. et al. [13].

${ }^{1} \mathrm{H}$ and ${ }^{13} \mathrm{C}$ NMR spectra were recorded either on a Bruker AVIII operating at $300 \mathrm{MHz}$ for ${ }^{1} \mathrm{H}$ and fitted with a $5 \mathrm{~mm}$ BBFO probe or on a Bruker AVANCE NEO operating at $400 \mathrm{MHz}$ for ${ }^{1} \mathrm{H}$ fitted with a $5 \mathrm{~mm}$ "smart" BBFO probe, respectively. ${ }^{1} \mathrm{H}-{ }^{1} \mathrm{H}$ COSY, ${ }^{1} \mathrm{H}_{-}-{ }^{13} \mathrm{C}$ and ${ }^{1} \mathrm{H}-{ }^{15} \mathrm{~N}$ HSQC,,${ }^{1} \mathrm{H}^{-13} \mathrm{C}$ and ${ }^{1} \mathrm{H}_{-}{ }^{15} \mathrm{~N}$ HMBC NMR spectra were recorded on a Bruker AVANCE NEO console operating at $500 \mathrm{MHz}$ for ${ }^{1} \mathrm{H}$ and fitted with a nitrogen-cooled BBFO probe. Chemical shift data for ${ }^{1} \mathrm{H}$ are reported in parts per million (ppm, $\delta$ scale) downfield from tetramethylsilane (TMS: $\delta 0.0)$ and referenced internally to the residual proton in the solvent. The deuterated solvents used for NMR analysis were: chloroform $\left(\mathrm{CDCl}_{3}: \delta \mathrm{H} 7.26, \delta \mathrm{C} 77.2\right)$, dimethyl sulfoxide (DMSO- $\left.d_{6}: \delta \mathrm{H} 2.50, \delta \mathrm{C} 39.5\right)$, and methanol $\left(\mathrm{CD}_{3} \mathrm{OD}\right.$ : $\delta \mathrm{H} 3.31, \delta \mathrm{C} 49.0)$. Coupling constants $(J)$ are given in hertz $(\mathrm{Hz})$. The data are presented as follows: chemical shift, multiplicity $(\mathrm{s}=$ singlet, $\mathrm{d}=$ doublet, $\mathrm{t}=$ triplet, $\mathrm{q}=$ quartet, $\mathrm{p}=$ pentet, $\mathrm{m}=$ multiple, $\mathrm{br}=$ broad, app = apparent and combinations thereof), coupling constant and integration.

Mass spectra data were recorded using a Waters ${ }^{\circledR}$ Xevo G2-XS TOF using electro-spray ionization in positive (ESI+) mode.

\subsection{Synthesis of Piperine-Inspired Molecules}

Synthesis of Piperonal (2)

To a stirred solution of piperonyl alcohol (1) $(152 \mathrm{mg}, 1.0 \mathrm{mmol})$ in DCM (100 mL), manganese dioxide $(1739 \mathrm{mg}, 20.0 \mathrm{mmol})$ was added at a rate of $1.0 \mathrm{mmol} / \mathrm{h}$ until completion. The reaction mixture was filtered through a pad of Celite ${ }^{\circledR}$ and the filtrate was concentrated in vacuo to afford the desired compound as white crystals (148 mg, 97\%). ${ }^{1} \mathrm{H} \mathrm{NMR}\left(300 \mathrm{MHz}, \mathrm{CDCl}_{3}\right) \delta 9.81(\mathrm{~s}, 1 \mathrm{H}), 7.41(\mathrm{dd}, J=7.9$, $1.5 \mathrm{~Hz}, 1 \mathrm{H}), 7.33(\mathrm{~d}, J=1.5 \mathrm{~Hz}, 1 \mathrm{H}), 6.93(\mathrm{~d}, J=7.9 \mathrm{~Hz}, 1 \mathrm{H}), 6.08(\mathrm{~s}, 2 \mathrm{H}) ;{ }^{13} \mathrm{C} \mathrm{NMR}(101 \mathrm{MHz}, \mathrm{CDCl} 3) \delta$ $190.5,153.3,148.9,132.1,128.9,108.5,107.1,102.3$. Data were in accordance with the literature [26].

Synthesis of (E)-3-(Benzo[d][1,3]dioxol-5-yl)-1-phenylprop-2-en-1-one (3a)

Acetophenone (240 mg, $2.0 \mathrm{mmol}), 2(300 \mathrm{mg}, 2.0 \mathrm{mmol})$, ethanol $(95 \%, 1.0 \mathrm{~mL})$ and sodium hydroxide solution $\left(10 \% w / w\right.$ in $\left.\mathrm{H}_{2} \mathrm{O}, 1.0 \mathrm{~mL}\right)$ were added to a round-bottom flask. The reaction mixture was stirred at room temperature for $5 \mathrm{~h}$. The reaction mixture was washed with ethanol $(100 \mathrm{~mL})$ and filtered under vacuum. The solid was dried in vacuo to afford the desired compound as a yellow powder $(270 \mathrm{mg}, 90 \%) .{ }^{1} \mathrm{H} \mathrm{NMR}\left(300 \mathrm{MHz}, \mathrm{CDCl}_{3}\right) \delta 8.06-7.95(\mathrm{~m}, 2 \mathrm{H}), 7.74(\mathrm{~d}, J=15.6 \mathrm{~Hz}, 1 \mathrm{H})$, 7.63-7.46 (m, 3H), $7.37(\mathrm{~d}, J=15.6 \mathrm{~Hz}, 1 \mathrm{H}), 7.19-7.08(\mathrm{~m}, 2 \mathrm{H}), 6.85(\mathrm{~d}, J=8.0 \mathrm{~Hz}, 1 \mathrm{H}), 6.03(\mathrm{~s}, 2 \mathrm{H}) ;{ }^{13} \mathrm{C}$ NMR (101 MHz, $\left.\mathrm{CDCl}_{3}\right) \delta 190.6,150.1,148.6,144.9,138.6,132.8,129.5,128.8,128.6,125.5,120.3,108.9$, 106.8, 101.8; LRMS $\left(\mathrm{ES}^{+}\right) \mathrm{m} / z: 253.09[\mathrm{M}+\mathrm{H}]^{+}$; $\mathrm{HRMS}_{\left(\mathrm{ES}^{+}\right)}$m/z calcd. $\mathrm{C}_{6} \mathrm{H}_{13} \mathrm{O}_{3}[\mathrm{M}+\mathrm{H}]^{+}=253.0865$; observed $253.0860(-2.0 \mathrm{ppm})$.

Synthesis of (E)-3-(Benzo[d][1,3]dioxol-5-yl)-1-(3-nitrophenyl)prop-2-en-1-one (3b)

A round bottom flask was charged with 3-nitroacetophenone (330.3 mg, $2.0 \mathrm{mmol}), 2$ (300.3 mg, $2.0 \mathrm{mmol})$, ethanol $(95 \%, 1.0 \mathrm{~mL})$, and sodium hydroxide solution $\left(10 \% w / w\right.$ in $\left.\mathrm{H}_{2} \mathrm{O}, 1.0 \mathrm{~mL}\right)$. The mixture was stirred at room temperature for $5 \mathrm{~h}$. The mixture was washed with ethanol $(100 \mathrm{~mL})$ and filtered under vacuum. The powder was recrystallized from hot ethanol and the product was afforded as orange crystals $(240 \mathrm{mg}, 80 \%) .{ }^{1} \mathrm{H}$ NMR $\left(400 \mathrm{MHz}, \mathrm{CDCl}_{3}\right) \delta 8.82(\mathrm{t}, J=1.9 \mathrm{~Hz}, 1 \mathrm{H}), 8.43$ (ddd, $J=8.2$, 2.3, $1.1 \mathrm{~Hz}, 1 \mathrm{H}), 8.33(\mathrm{ddd}, J=7.8,1.7,1.1 \mathrm{~Hz}, 1 \mathrm{H}), 7.81(\mathrm{~d}, J=15.5 \mathrm{~Hz}, 1 \mathrm{H}), 7.71(\mathrm{t}, J=8.0 \mathrm{~Hz}, 1 \mathrm{H}), 7.36$ $(\mathrm{d}, J=15.5 \mathrm{~Hz}, 1 \mathrm{H}), 7.21-7.14(\mathrm{~m}, 2 \mathrm{H}), 6.87(\mathrm{~d}, J=8.0 \mathrm{~Hz}, 1 \mathrm{H}), 6.05(\mathrm{~s}, 2 \mathrm{H}) ;{ }^{13} \mathrm{C}$ NMR $\left(101 \mathrm{MHz}, \mathrm{CDCl}_{3}\right)$ $\delta$ 188.0, 150.7, 148.7, 148.6, 146.8, 139.9, 134.2, 130.0, 128.9, 127.10, 126.1, 123.4, 118.7, 108.9, 106.9, 102.0; LRMS $\left(\mathrm{ES}^{+}\right) \mathrm{m} / \mathrm{z}: 298.07[\mathrm{M}+\mathrm{H}]^{+}$; HRMS $\left(\mathrm{ES}^{+}\right) \mathrm{m} / z$ : calcd. $\mathrm{C}_{16} \mathrm{H}_{12} \mathrm{NO}_{5}[\mathrm{M}+\mathrm{H}]^{+}=298.0715$; observed 298.0712 (1.0 ppm). 
Synthesis of (E)-1-(3-Aminophenyl)-3-(benzo[d][1,3]dioxol-5-yl)prop-2-en-1-one (3c)

A round bottom flask was charged with 3-aminoacetophenone (270.3 mg, $2.0 \mathrm{mmol}), 2$ (300.3 mg, $2.0 \mathrm{mmol})$, ethanol $(95 \%, 1.0 \mathrm{~mL})$, and sodium hydroxide solution $\left(10 \% w / w\right.$ in $\left.\mathrm{H}_{2} \mathrm{O}, 1.0 \mathrm{~mL}\right)$. The mixture was stirred at room temperature for $5 \mathrm{~h}$. The mixture was washed with ethanol $(100 \mathrm{~mL})$ and filtered under vacuum. The crude product was purified by column chromatography $\left(\mathrm{SiO}_{2} ; \mathrm{EtOAc} /\right.$ hexane 1:1) to afford the product as a yellow powder $(240.2 \mathrm{mg}, 80 \%) .{ }^{1} \mathrm{H} \mathrm{NMR}\left(300 \mathrm{MHz}, \mathrm{CDCl}_{3}\right) \delta 7.73(\mathrm{~d}$, $J=15.6 \mathrm{~Hz}, 1 \mathrm{H}), 7.39(\mathrm{ddd}, J=7.7,1.7,1.1 \mathrm{~Hz}, 1 \mathrm{H}), 7.37-7.27(\mathrm{~m}, 3 \mathrm{H}), 7.18-7.10(\mathrm{~m}, 2 \mathrm{H}), 6.90(\mathrm{ddd}$, $J=7.9,2.5,1.1 \mathrm{~Hz}, 1 \mathrm{H}), 6.85(\mathrm{~d}, J=8.0 \mathrm{~Hz}, 1 \mathrm{H}), 6.04(\mathrm{~s}, 2 \mathrm{H}), 3.85(\mathrm{~s}, 2 \mathrm{H}) ;{ }^{13} \mathrm{C} \mathrm{NMR}\left(101 \mathrm{MHz}, \mathrm{CDCl}_{3}\right) \delta$ 190.7, 150.01, 148.6, 147.0, 144.5, 139.7, 129.6, 129.6, 125.3, 120.6, 119.5, 118.9, 114.6, 108.8, 106.8, 101.8; LRMS $\left(\mathrm{ES}^{+}\right) \mathrm{m} / z: 268.10[\mathrm{M}+\mathrm{H}]^{+} ; \mathrm{HRMS}_{\left(\mathrm{ES}^{+}\right)} \mathrm{m} / z$ : calcd. $\mathrm{C}_{16} \mathrm{H}_{14} \mathrm{NO}_{3}[\mathrm{M}+\mathrm{H}]^{+}=268.0974$; observed $268.0974(0.0 \mathrm{ppm})$.

Synthesis of 5-(Benzo[d][1,3]dioxol-5-yl)-3-phenyl-4,5-dihydro-1H-pyrazole-1-carbothioamide (4a)

Ethanol (95\%, $25 \mathrm{~mL}), \mathrm{NaOH}(1.0 \mathrm{~g}, 0.025 \mathrm{~mol}), 3 \mathrm{a}(2.52 \mathrm{~g}, 0.01 \mathrm{~mol})$ and thiosemicarbazide $(911 \mathrm{mg}, 0.01 \mathrm{~mol})$ were added to a round-bottom flask. The reaction mixture was stirred for $3 \mathrm{~h}$ at reflux. Upon completion, the reaction mixture was added to ice. The resulting precipitate was washed with diethyl ether $(100 \mathrm{~mL})$ and water $(100 \mathrm{~mL})$ under vacuum filtration. The white powder was recrystallized from hot ethanol to afford the desired product as white crystals $(1.51 \mathrm{~g}, 60 \%) .{ }^{1} \mathrm{H} \mathrm{NMR}$ $\left(300 \mathrm{MHz}, \mathrm{CDCl}_{3}\right)$ 8 7.79-7.66 (m, 2H), 7.52-7.37 (m, 3H), $7.09(\mathrm{~s}, 1 \mathrm{H}), 6.86-6.57(\mathrm{~m}, 3 \mathrm{H}), 6.31-5.76$ $(\mathrm{m}, 4 \mathrm{H}), 3.81(\mathrm{dd}, J=17.7,11.4 \mathrm{~Hz}, 1 \mathrm{H}), 3.18(\mathrm{dd}, J=17.8,3.6 \mathrm{~Hz}, 1 \mathrm{H}) ;{ }^{13} \mathrm{C} \mathrm{NMR}\left(126 \mathrm{MHz}, \mathrm{CDCl}_{3}\right)$ $\delta 176.9,156.2,148.3,147.2,135.9,131.3,130.8,129.1,127.1,119.2,108.7,106.1,101.3,63.5,43.4 ;{ }^{15} \mathrm{~N}$ NMR (51 MHz, $\left.\mathrm{CDCl}_{3}\right) \delta 194.9 ; 101.3 ; 13.3 ; \mathrm{LRMS}_{\left(\mathrm{ES}^{+}\right)} \mathrm{m} / z: 326.10[\mathrm{M}+\mathrm{H}]^{+}$; HRMS $\left(\mathrm{ES}^{+}\right) \mathrm{m} / z$ : calcd. $\mathrm{C}_{17} \mathrm{H}_{16} \mathrm{~N}_{3} \mathrm{O}_{2} \mathrm{~S}[\mathrm{M}+\mathrm{H}]^{+}=326.0963$; observed 326.0968 (1.5 ppm).

Synthesis of 3-(3-Aminophenyl)-5-(benzo[d][1,3]dioxol-5-yl)-4,5-dihydro-1H-pyrazole-1carbothioamide (4c)

A round-bottom flask was charged with ethanol (95\%, $25 \mathrm{~mL}) \mathrm{NaOH}(1000 \mathrm{mg}, 0.025 \mathrm{~mol}$ ), $3 \mathrm{c}$ (2673 $\mathrm{mg} 0.01 \mathrm{~mol}$ ) and thiosemicarbazide $(911 \mathrm{mg}, 0.01 \mathrm{~mol})$. The reaction mixture was stirred for $3 \mathrm{~h}$ at reflux. Upon completion, the reaction mixture was added to ice. The resulting solid was washed with diethyl ether and water, then filtered. The crude product was purified by column chromatography $\left(\mathrm{SiO}_{2} ; \mathrm{EtOAc} /\right.$ hexane 7:3) to afford the desired compound as an off-yellow powder $(1604 \mathrm{mg}, 60 \%) .{ }^{1} \mathrm{H}$ NMR $\left(500 \mathrm{MHz}\right.$, DMSO- $\left.d_{6}\right) \delta 7.98(\mathrm{~s}, 1 \mathrm{H}), 7.67(\mathrm{~s}, 1 \mathrm{H}), 7.08(\mathrm{app} \mathrm{t}, J=7.8 \mathrm{~Hz}, 1 \mathrm{H}), 7.03(\mathrm{~d}$ app t,$J=7.8$, $1.1 \mathrm{~Hz}, 1 \mathrm{H}), 6.99(\mathrm{app} \mathrm{t}, J=2 \mathrm{~Hz}, 1 \mathrm{H}), 6.83(\mathrm{~d}, J=8.0 \mathrm{~Hz}, 1 \mathrm{H}), 6.67(\mathrm{ddd}, J=7.9,2.3,1.1 \mathrm{~Hz}, 1 \mathrm{H}), 6.63(\mathrm{~d}$, $J=1.7 \mathrm{~Hz}, 1 \mathrm{H}), 6.59(\mathrm{dd}, J=8.1,1.8 \mathrm{~Hz}, 1 \mathrm{H}), 5.99-5.95(\mathrm{~m}, 2 \mathrm{H}), 5.81(\mathrm{dd}, J=11.2,3.1 \mathrm{~Hz}, 1 \mathrm{H}), 5.18(\mathrm{~s}$, $2 \mathrm{H}), 3.81(\mathrm{dd}, J=17.9,11.3 \mathrm{~Hz}, 1 \mathrm{H}), 2.98(\mathrm{dd}, J=17.8,3.2 \mathrm{~Hz}, 1 \mathrm{H}) ;{ }^{13} \mathrm{C}$ NMR $\left(126 \mathrm{MHz}\right.$, DMSO- $\left.d_{6}\right) \delta$ 175.9, 155.8, 148.8, 147.2, 146.1, 136.9, 131.3, 129.1, 118.3, 116.2, 114.8, 112.0, 108.2, 105.8, 100.9, 62.4, 42.6; ${ }^{15} \mathrm{~N}$ NMR $\left(51 \mathrm{MHz}, \mathrm{CDCl}_{3}\right) \delta 192.6 ; 108.6 ; 60.9 ; 14.6$; LRMS $\left(\mathrm{ES}^{+}\right) \mathrm{m} / z: 341.11[\mathrm{M}+\mathrm{H}]^{+} ; \mathrm{HRMS}\left(\mathrm{ES}^{+}\right.$) m/z: calcd. $\mathrm{C}_{17} \mathrm{H}_{17} \mathrm{~N}_{4} \mathrm{O}_{2} \mathrm{~S}[\mathrm{M}+\mathrm{H}]^{+}=341.1072$; observed 341.1076 (1.2 ppm).

\subsection{Synthesis of PPL-Inspired Molecules}

Synthesis of (E)-3-(3,4,5-Trimethoxyphenyl)acrylic acid (7a)

Malonic acid $(1.24 \mathrm{~g}, 12 \mathrm{mmol})$ was added to a stirred solution of $6 \mathrm{a}(1.94 \mathrm{~g}, 10 \mathrm{mmol})$, pyridine $(6.0 \mathrm{~mL})$ and piperidine $(0.6 \mathrm{~mL})$. The reaction was stirred at reflux for $4 \mathrm{~h}$. The mixture was then cooled

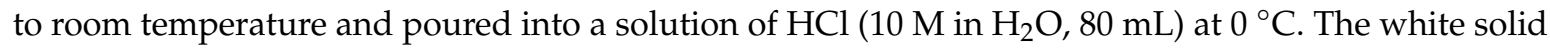
that formed was recovered by filtration and washed with water $(200 \mathrm{~mL})$ to afford the title compound as yellow powder $(1.65 \mathrm{~g}, 85 \%) .{ }^{1} \mathrm{H}$ NMR $\left(300 \mathrm{MHz}, \mathrm{CDCl}_{3}\right) \delta 7.71(\mathrm{~d}, J=15.8 \mathrm{~Hz}, 1 \mathrm{H}), 6.78(\mathrm{~s}, 2 \mathrm{H})$, $6.36(\mathrm{~d}, J=15.9 \mathrm{~Hz}, 1 \mathrm{H}), 3.90(\mathrm{~s}, 6 \mathrm{H}), 3.89(\mathrm{~s}, 3 \mathrm{H}) .{ }^{13} \mathrm{C} \mathrm{NMR}\left(101 \mathrm{MHz}, \mathrm{CDCl}_{3}\right) \delta 172.4,153.6,147.3$,

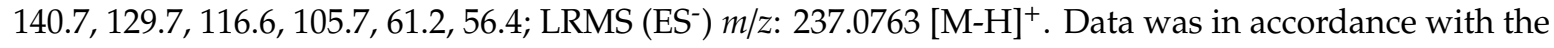
literature [27]. 
Synthesis of (E)-3-(4-Methoxyphenyl)acrylic acid (7b)

Malonic acid (1.24 g, $12 \mathrm{mmol})$ was added to a stirred solution of $6 \mathbf{b}(1.36 \mathrm{~g}, 10 \mathrm{mmol})$, pyridine $(6 \mathrm{~mL})$ and piperidine $(0.6 \mathrm{~mL})$. The reaction was stirred at reflux for $4 \mathrm{~h}$. The mixture was then cooled to room temperature and poured into a solution of $\mathrm{HCl}\left(10 \mathrm{M}\right.$ in $\left.\mathrm{H}_{2} \mathrm{O}, 80 \mathrm{~mL}\right)$ at $0{ }^{\circ} \mathrm{C}$. The white solid that formed was recovered by filtration and washed with water $(200 \mathrm{~mL})$ to afford the title compound as white powder $(1.33 \mathrm{~g}, 98 \%) .{ }^{1} \mathrm{H}$ NMR $\left(300 \mathrm{MHz}, \mathrm{CD}_{3} \mathrm{OD}\right) \delta 7.62(\mathrm{~d}, J=16.0 \mathrm{~Hz}, 1 \mathrm{H}), 7.58-7.47$ $(\mathrm{m}, 2 \mathrm{H}), 7.01-6.88(\mathrm{~m}, 2 \mathrm{H}), 6.33(\mathrm{~d}, J=15.9 \mathrm{~Hz}, 1 \mathrm{H}), 3.82(\mathrm{~s}, 3 \mathrm{H})$. Data were in accordance with the literature [28].

Synthesis of (E)-3-(3,4,5-Trimethoxyphenyl)acryloyl chloride (8a)

To a stirred solution of $7 \mathbf{a}(714 \mathrm{mg}, 3.0 \mathrm{mmol})$ in DCM $(6.0 \mathrm{~mL})$, thionyl chloride $(0.65 \mathrm{~mL}, 9.0 \mathrm{mmol})$ and DMF $(0.01 \mathrm{~mL})$ were added. The reaction was stirred at reflux for $5 \mathrm{~h}$ under argon. The solvent was removed under reduced pressure and dried in vacuo to afford the title compound as a yellow powder $(707 \mathrm{mg}, 99 \%)$ and used immediately in the next step. ${ }^{1} \mathrm{H} \mathrm{NMR}\left(300 \mathrm{MHz}, \mathrm{CDCl}_{3}\right) \delta 7.75(\mathrm{~d}$, $J=15.4 \mathrm{~Hz}, 1 \mathrm{H}), 6.79(\mathrm{~s}, 2 \mathrm{H}), 6.55(\mathrm{~d}, J=15.4 \mathrm{~Hz}, 1 \mathrm{H}), 3.91(\mathrm{~s}, 3 \mathrm{H}), 3.91(\mathrm{~s}, 6 \mathrm{H})$.

Synthesis of (E)-3-(4-Methoxyphenyl)acryloyl chloride (8b)

To a stirred solution of $7 \mathbf{b}(534 \mathrm{mg}, 3.0 \mathrm{mmol})$ in DCM $(6.0 \mathrm{~mL})$, thionyl chloride $(0.65 \mathrm{~mL}$, $9.0 \mathrm{mmol})$ and DMF $(0.01 \mathrm{~mL})$ were added. The reaction was stirred at reflux for $5 \mathrm{~h}$ under argon. The solvent was removed under reduced pressure and dried in vacuo to afford the title compound as a yellow powder (513 mg, 96\%) and used immediately in the next step. ${ }^{1} \mathrm{H} \mathrm{NMR}\left(300 \mathrm{MHz}, \mathrm{CD}_{3} \mathrm{OD}\right) \delta$ $7.62(\mathrm{~d}, J=16.0 \mathrm{~Hz}, 1 \mathrm{H}), 7.58-7.47(\mathrm{~m}, 2 \mathrm{H}), 7.00-6.89(\mathrm{~m}, 2 \mathrm{H}), 6.33(\mathrm{~d}, J=15.9 \mathrm{~Hz}, 1 \mathrm{H}), 3.82(\mathrm{~s}, 3 \mathrm{H})$.

Synthesis of (E)-1-(3-(3,4,5-Trimethoxyphenyl)acryloyl)piperidin-2-one (9a)

To a stirred solution of $\delta$-valerolactam $(278 \mathrm{mg}, 2.8 \mathrm{mmol})$ in THF $(12 \mathrm{~mL})$ at $0{ }^{\circ} \mathrm{C}, \mathrm{NaH}(112 \mathrm{mg}$, $2.8 \mathrm{mmol}, 60 \% \mathrm{w} / \mathrm{w}$ in oil) was added slowly. The reaction was warmed to room temperature and stirred for $2 \mathrm{~h}$. The mixture was cooled to $0^{\circ} \mathrm{C}$ and $8 \mathbf{a}(641 \mathrm{mg}, 2.5 \mathrm{mmol})$ was added. The reaction was stirred for $1 \mathrm{~h}$ at $0^{\circ} \mathrm{C}$ and for a further $24 \mathrm{~h}$ at room temperature under argon. The solution was poured into ice water and stirred for $15 \mathrm{~min}$. The organic phase was recovered by extraction with ethyl acetate $(15 \mathrm{~mL})$, washed with brine $(30 \mathrm{~mL})$ and $\mathrm{NaOH}\left(2.0 \mathrm{M}\right.$ in $\left.\mathrm{H}_{2} \mathrm{O}, 30 \mathrm{~mL}\right)$ and dried $\left(\mathrm{MgSO}_{4}\right)$. The organic phase was concentrated by rotary evaporation under reduced pressure. The crude product was purified by column chromatography $\left(\mathrm{SiO}_{2} ; \mathrm{EtOAc} /\right.$ petroleum ether 1:1) to afford the title compound as a yellow powder $(219 \mathrm{mg}, 34 \%) .{ }^{1} \mathrm{H} \mathrm{NMR}\left(300 \mathrm{MHz}, \mathrm{CDCl}_{3}\right) \delta 7.63(\mathrm{~d}, J=15.5 \mathrm{~Hz}, 1 \mathrm{H}), 7.35(\mathrm{~d}, J=15.6 \mathrm{~Hz}, 1 \mathrm{H})$, $6.78(\mathrm{~s}, 2 \mathrm{H}), 3.88(\mathrm{~s}, 6 \mathrm{H}), 3.86(\mathrm{~s}, 3 \mathrm{H}), 3.79(\mathrm{td}, J=5.1,4.1,2.7 \mathrm{~Hz}, 2 \mathrm{H}), 2.68-2.53(\mathrm{~m}, 2 \mathrm{H}), 1.95-1.80(\mathrm{~m}$, $4 \mathrm{H})$. Data were in accordance with the literature [18].

Synthesis of (E)-1-(3-(4-Methoxyphenyl)acryloyl)piperidin-2-one (9b)

To a stirred solution of $\delta$-valerolactam $(278 \mathrm{mg}, 2.8 \mathrm{mmol})$ in THF $(12 \mathrm{~mL})$ at $0{ }^{\circ} \mathrm{C}, \mathrm{NaH}(112 \mathrm{mg}$, $2.8 \mathrm{mmol}, 60 \% \mathrm{w} / \mathrm{w}$ in oil) was added slowly. The reaction warmed to room temperature and stirred for $2 \mathrm{~h}$. The mixture was cooled to $0^{\circ} \mathrm{C}$ and $8 \mathbf{b}(490 \mathrm{mg}, 2.5 \mathrm{mmol})$ was added. The reaction was stirred for $1 \mathrm{~h}$ at $0{ }^{\circ} \mathrm{C}$ and for a further $24 \mathrm{~h}$ at room temperature under argon. The solution was poured into ice water and stirred for $15 \mathrm{~min}$. The organic phase was recovered by extraction with ethyl acetate $(15 \mathrm{~mL})$, washed with brine $(30 \mathrm{~mL})$ and $\mathrm{NaOH}\left(2.0 \mathrm{M}\right.$ in $\left.\mathrm{H}_{2} \mathrm{O}, 30 \mathrm{~mL}\right)$ and dried $\left(\mathrm{MgSO}_{4}\right)$. The organic phase was concentrated by rotary evaporation under reduced pressure. The crude product was purified by column chromatography $\left(\mathrm{SiO}_{2} ; \mathrm{EtOAc} /\right.$ petroleum ether 1:1) to afford the title compound as a yellow powder $(114 \mathrm{mg}, 23 \%) .{ }^{1} \mathrm{H}$ NMR $\left(300 \mathrm{MHz}, \mathrm{CDCl}_{3}\right) \delta 7.69(\mathrm{~d}, J=15.6 \mathrm{~Hz}, 1 \mathrm{H}), 7.57-7.47(\mathrm{~m}, 2 \mathrm{H}), 7.35$ $(\mathrm{d}, J=15.6 \mathrm{~Hz}, 1 \mathrm{H}), 6.95-6.81(\mathrm{~m}, 2 \mathrm{H}), 3.83(\mathrm{~s}, 3 \mathrm{H}), 3.79(\mathrm{td}, J=5.2,4.2,2.3 \mathrm{~Hz}, 2 \mathrm{H}), 2.66-2.54(\mathrm{~m}, 2 \mathrm{H})$, 1.93-1.84 $(\mathrm{m}, 4 \mathrm{H})$. Data were in accordance with the literature [29]. 
Synthesis (E)-6-(3-(3,4,5-Trimethoxyphenyl)acryloyl)cyclohex-2-en-1-one (10)

To a stirred solution of cyclohex-2-enone $(577 \mathrm{mg}, 6.0 \mathrm{mmol})$ in THF $(15.0 \mathrm{~mL})$ at $-78{ }^{\circ} \mathrm{C}$, lithium diisopropylamide $(0.6 \mathrm{~mL}, 6.0 \mathrm{mmol})$ was added dropwise. The solution was stirred at $-78{ }^{\circ} \mathrm{C}$ for $45 \mathrm{~min}$ under argon. A solution of $\mathbf{8 a}(770 \mathrm{mg}, 3.0 \mathrm{mmol})$ in THF $(15 \mathrm{~mL})$ was slowly added to the initial solution and stirred for a further $1 \mathrm{~h}$ at $-78^{\circ} \mathrm{C}$, then $1 \mathrm{~h}$ at $0{ }^{\circ} \mathrm{C}$. The organic phase was recovered by extraction with ethyl acetate $(15 \mathrm{~mL})$, washed with brine $(30 \mathrm{~mL})$, and dried $\left(\mathrm{MgSO}_{4}\right)$. The crude product was purified by column chromatography $\left(\mathrm{SiO}_{2} ; \mathrm{EtOAc} /\right.$ petroleum ether 1:1) to afford the title compound as a yellow powder $(228 \mathrm{mg}, 40 \%) .{ }^{1} \mathrm{H} \mathrm{NMR}\left(300 \mathrm{MHz}, \mathrm{CDCl}_{3}\right) \delta 15.76(\mathrm{t}, J=1.1 \mathrm{~Hz}, 1 \mathrm{H})$, $7.55(\mathrm{~d}, J=15.5 \mathrm{~Hz}, 1 \mathrm{H}), 6.90-6.80(\mathrm{~m}, 2 \mathrm{H}), 6.76(\mathrm{~s}, 2 \mathrm{H}), 6.16(\mathrm{dtd}, J=10.0,2.0,0.9 \mathrm{~Hz}, 1 \mathrm{H}), 3.90(\mathrm{~d}$, $J=1.0 \mathrm{~Hz}, 6 \mathrm{H}), 3.88(\mathrm{~d}, J=0.9 \mathrm{~Hz}, 3 \mathrm{H}), 2.75(\mathrm{t}, J=7.2 \mathrm{~Hz}, 2 \mathrm{H}), 2.42(\mathrm{qd}, J=5.3,4.7,2.6 \mathrm{~Hz}, 2 \mathrm{H})$. Data were in accordance with the literature [29] except the signal at $15.76 \mathrm{ppm}$.

\subsection{Electronic Structure Characterization}

The molecular structures of the analogues Piperine and PPL were built in Avogadro software [30] and optimized by $a b$ initio calculation. The calculations were performed using the Gamess2018 quantum mechanics package [31,32] with Hartree-Fock (HF) formalism [33] and density functional theory (DFT) [34]. 6-311+G(1d,1p) was used as the set of the bases and B3LYP as the functional [35]. The optimized geometries were determined with a Polarizable Continuum Model (PCM) solvent model [36] for $\mathrm{H}_{2} \mathrm{O}$ and 4a was also optimized in $\mathrm{CHCl}_{3}$. The optimizations were followed by harmonic frequency calculations to obtain the vibrational, the rotational, and the translational contributions to the free energy. The electrostatic potential map and the partial charges were determined using the geodesic method [37] along with the same functional base set and solvent model used for the optimization of the structure. The structure and the normal frequency modes analyses were visualized by wxMacMolPlt software [38] to assure that the result is not a structure in a transition state.

\subsection{Molecular Docking}

The optimized structures of each analogue were obtained from Section 3.3. IL-1 $\beta$ structure was obtained from chain A of PDB-1ITB and p65 unit of NF- $\mathrm{kB}$ was obtained from the chain A of PDB-2O61.

AutoDockTools [39] software of the MGL program Tools 1.5.4 was used to prepare the proteins by adding polar hydrogen atoms and Gasteiger charges. Blind docking was performed to explore the whole IL-1 $\beta$ protein. The maps were generated by AutoGrid 4.2 program with a spacing of $0.4583 \AA$, dimension of $126 \times 126 \times 108$ points and grid center coordinates as being $41.028,-0.369$ and 12.346 for $x$, $\mathrm{y}$ and $\mathrm{z}$ coordinates, respectively. The NF- $\mathrm{kB}$ maps were generated by AutoGrid 4.2 program [39] with a spacing of $0.375 \AA$, dimension of $90 \times 82 \times 92$ points and grid center coordinates as being 21.573, -12.537 and -0.788 for $x, y$ and $z$ coordinates, respectively. AutoDock 4.2[39] was used to investigate the protein binding site using the Lamarckian Genetic Algorithm (LGA) with a population size of 150 , maximum number of generations of 27000 and energy evaluations equal to $2.5 \times 10^{6}$. The other parameters were selected as the software default. To generate different conformations, the total numbers of runs were set to 100 . The final energy scores were calculated following the equation

$$
\Delta G=\left(V_{\text {bound }}^{L-L}-V_{\text {umbound }}^{L-L}\right)+\left(V_{\text {bound }}^{P-P}-V_{\text {umbound }}^{P-P}\right)+\left(V_{\text {bound }}^{P-L}-V_{\text {umbound }}^{P-L}\right)+\Delta S_{\text {conformation }} .
$$

The potentials utilized to perform the calculation were the following:

$$
V(\text { energy score })=I \cdot \sum_{i, j}\left(\frac{A_{i j}}{r_{i j}^{12}}-\frac{B_{i j}}{r_{i j}^{6}}\right)+J \cdot \sum_{i, j} E(t) \cdot\left(\frac{C_{i j}}{r_{i j}^{12}}-\frac{D_{i j}}{r_{i j}^{10}}\right)+K \cdot \sum_{i, j} \frac{q_{i} \cdot q_{j}}{\varepsilon \cdot r_{i j}^{2}}+\Delta W
$$

The weighting constants I, J, E(t) and $\mathrm{K}$ are those optimized to calibrate the empirical free energy based on a set of experimentally characterized complexes. The first term is the Lenard-Jones potential, in which parameters A and B are taken from the Amber force field. The second term refers to the 
hydrogen bond in which parameters $\mathrm{C}$ and $\mathrm{D}$ are obtained to ensure a minimum energy of $5.0 \mathrm{kcal} / \mathrm{mol}$ in $1.9 \AA$ for $\mathrm{O}-\mathrm{H}$ and N-H and $1.0 \mathrm{kcal} / \mathrm{mol}$ in $2.5 \AA$ for S-H [40]. The function $\mathrm{E}(\mathrm{t})$ provides directionality based on the angle $t$ of the geometry of an ideal hydrogen bond. The third term is a shielded Coulomb potential for electrostatic interaction. The last term is the desolvation potential based on the volume of the atoms surrounding a given atom and sheltering of the solvent [40]. The final conformations were chosen among the most negative energies that belong to the most representative cluster and visualized by visual molecular dynamics software (VMD) [41]. The binding microenvironment was generated by LigPlot [42].

\section{Conclusions}

In this study, we have confirmed the structure of some ambiguous complex natural product -likescaffolds from the literature through de novo synthesis, spectroscopic analysis including ${ }^{15} \mathrm{~N} \mathrm{NMR}$ techniques, and ab initio calculations. With the definitive structures in hand, we used molecular docking to investigate the rationale for the promising biological results these molecules exhibit in the inhibition of the inflammatory response (via downregulation of IL-1 $\beta$ and NF- $\mathrm{kB}$ pathway). This work revealed $\mathbf{3 a}, \mathbf{c}, \mathbf{4 a}, \mathbf{c}$ and $\mathbf{1 0}$ as the most promising molecules to be evaluated as IL-1 $\beta$ and NF- $\mathrm{kB}$ inhibitors in future studies.

Supplementary Materials: The following are available online, copies of ${ }^{1} \mathrm{H},{ }^{13} \mathrm{C}$ and 2D NMR spectra, and $a b$ initio calculations of selected dihedral angles.

Author Contributions: Conceptualization, M.L.C. and A.M.J.; methodology, M.L.C., A.M.J., A.P.R.P. and G.Z.; software, A.P.R.P. and G.Z.; validation, B.T. and C.S.L.D., formal analysis, M.L.C., C.S.L.D., and A.M.J.; investigation, A.P.R.P., G.Z., B.T. and C.S.L.D.; resources, A.M.J., B.T. and C.S.L.D.; data curation, A.P.R.P., G.Z. and A.M.J.; writing—original draft preparation, A.P.R.P., G.Z. and A.M.J.; writing—review and editing, A.M.J., A.P.R.P., G.Z., M.L.C. and C.S.L.D.; visualization, A.P.R.P. and G.Z.; supervision, A.M.J. and M.L.C.; project administration, A.M.J; funding acquisition, M.L.C, A.M.J, A.P.R.P. and G.Z. All authors have read and agreed to the published version of the manuscript.

Funding: This study was financed in part by the Coordenação de Aperfeiçoamento de Pessoal de Nível Superior-Brasil (CAPES)-Finance Code 001 in the form of research scholarships for A.P.R.P. and G.Z. The APC was funded by Molecules, MDPI.

Acknowledgments: The computations described in this paper were performed using the University of Birmingham's BlueBEAR HPC service, which provides a High Performance Computing service to the University's research community. See http://www.birmingham.ac.uk/bear for more details.

Conflicts of Interest: The authors declare no conflict of interest.

\section{References}

1. Collins, I.; Jones, A.M. Diversity-oriented synthetic strategies applied to cancer chemical biology and drug discovery. Molecules 2014, 19, 17221-17255. [CrossRef] [PubMed]

2. Newman, D.J. Natural products as leads to potential drugs: An old process or the new hope for drug discovery? J. Med. Chem. 2008, 51, 2589-2599. [CrossRef] [PubMed]

3. Srinivasan, K. Black pepper and its pungent principle-piperine: A review of diverse physiological effects. Crit. Rev. Food Sci. Nutr. 2007, 47, 735-748. [CrossRef] [PubMed]

4. Umadevi, P.; Deepti, K.; Venugopal, D.V.R. Synthesis, anticancer and antibacterial activities of piperine analogs. Med. Chem. Res. 2013, 22, 5466-5471. [CrossRef]

5. Venkatasamy, R.; Faas, L.; Young, A.R.; Raman, A.; Hider, R.C. Effects of piperine analogues on stimulation of melanocyte proliferation and melanocyte differentiation. Bioorg. Med. Chem. 2004, 12, 1905-1920. [CrossRef] [PubMed]

6. Bezerra, D.P.; Pessoa, C.; de Moraes, M.O.; Saker-Neto, N.; Silveira, E.R.; Costa-Lotufo, L.V. Overview of the therapeutic potential of piplartine (piperlongumine). Eur. J. Pharm. Sci. 2013, 48, 453-463. [CrossRef]

7. Adams, D.J.; Dai, M.; Pellegrino, G.; Wagner, B.K.; Stern, A.M.; Shamji, A.F.; Schreiber, S.L. Synthesis, cellular evaluation, and mechanism of action of piperlongumine analogs. Proc. Natl. Acad. Sci. USA 2012, 109, 15115-15120. [CrossRef] 
8. Piska, K.; Gunia-Krzyżak, A.; Koczurkiewicz, P.; Wójcik-Pszczoła, K.; Pękala, E. Piperlongumine (piplartine) as a lead compound for anticancer agents - Synthesis and properties of analogues: A mini-review. Eur. J. Med. Chem. 2018, 156, 13-20. [CrossRef]

9. Meghwal, M.; Goswami, T.K. Piper nigrum and piperine: An update. Phyther. Res. 2013, 27, 1121-1130. [CrossRef]

10. Bang, J.S.; Oh, D.H.; Choi, H.M.; Sur, B.-J.; Lim, S.-J.; Kim, J.Y.; Yang, H.I.; Yoo, M.C.; Hahm, D.-H.; Kim, K.S. Anti-inflammatory and antiarthritic effects of piperine in human interleukin $1 \beta$-stimulated fibroblast-like synoviocytes and in rat arthritis models. Arthritis Res. Ther. 2009, 11, R49. [CrossRef]

11. Ying, X.; Chen, X.; Cheng, S.; Shen, Y.; Peng, L.; Xu, H. Piperine inhibits IL- $\beta$ induced expression of inflammatory mediators in human osteoarthritis chondrocyte. Int. Immunopharmacol. 2013, 17, $293-299$. [CrossRef] [PubMed]

12. Ying, X.; Yu, K.; Chen, X.; Chen, H.; Hong, J.; Cheng, S.; Peng, L. Piperine inhibits LPS induced expression of inflammatory mediators in RAW 264.7 cells. Cell. Immunol. 2013, 285, 49-54. [CrossRef] [PubMed]

13. Mathew, A.; Sheeja, M.T.L.; Kumar, K.; Radha, A.T. Design, synthesis and biological evaluation of pyrazole analogues of natural piperine. Hygeia JD Med. 2011, 3, 48-56.

14. Qu, H.; Lv, M.; Xu, H. Piperine: Bioactivities and structural modifications. Mini Rev. Med. Chem. 2015, 15, 145-156. [CrossRef]

15. Prasad, S.; Tyagi, A.K. Historical spice as a future drug: Therapeutic potential of piperlongumine. Curr. Pharm. Des. 2016, 22, 4151-4159. [CrossRef]

16. Wu, Y.; Min, X.; Zhuang, C.; Li, J.; Yu, Z.; Dong, G.; Yao, J.; Wang, S.; Liu, Y.; Wu, S. Design, synthesis and biological activity of piperlongumine derivatives as selective anticancer agents. Eur. J. Med. Chem. 2014, 82, 545-551. [CrossRef]

17. Ginzburg, S.; Golovine, K.V.; Makhov, P.B.; Uzzo, R.G.; Kutikov, A.; Kolenko, V.M. Piperlongumine inhibits NF- $\mathrm{KB}$ activity and attenuates aggressive growth characteristics of prostate cancer cells. Prostate 2014, 74, 177-186. [CrossRef]

18. Sun, L.-D.; Wang, F.; Dai, F.; Wang, Y.-H.; Lin, D.; Zhou, B. Development and mechanism investigation of a new piperlongumine derivative as a potent anti-inflammatory agent. Biochem. Pharmacol. 2015, 95, 156-169. [CrossRef]

19. Si, D.; Wang, Y.; Zhou, Y.-H.; Guo, Y.; Wang, J.; Zhou, H.; Li, Z.-S.; Fawcett, J.P. Mechanism of CYP2C9 inhibition by flavones and flavonols. Drug Metab. Dispos. 2009, 37, 629-634. [CrossRef]

20. Gu, S.M.; Lee, H.P.; Ham, Y.W.; Son, D.J.; Kim, H.Y.; Oh, K.W.; Han, S.-B.; Yun, J.; Hong, J.T. Piperlongumine improves lipopolysaccharide-induced amyloidogenesis by suppressing NF-KappaB pathway. Neuromol. Med. 2018, 20, 312-327. [CrossRef]

21. Zazeri, G.; Povinelli, A.P.R.; de Lima, F.M.; Cornélio, M.L. Experimental approaches and computational modeling of rat serum albumin and its interaction with piperine. Int. J. Mol. Sci. 2019, 20, 2856. [CrossRef] [PubMed]

22. Povinelli, A.P.R.; Zazeri, G.; de Freitas Lima, M.; Cornélio, M.L. Details of the cooperative binding of piperlongumine with rat serum albumin obtained by spectroscopic and computational analyses. Sci. Rep. 2019, 9, 1-11. [CrossRef] [PubMed]

23. Panne, D.; Maniatis, T.; Harrison, S.C. An atomic model of the interferon- $\beta$ enhanceosome. Cell 2007, 129, 1111-1123. [CrossRef] [PubMed]

24. Chen, Y.-Q.; Ghosh, S.; Ghosh, G. A novel DNA recognition mode by the NF-кB p65 homodimer. Nat. Struct. Biol. 1998, 5, 67-73. [CrossRef] [PubMed]

25. Williams, D.B.G.; Lawton, M. Drying of organic solvents: Quantitative evaluation of the efficiency of several desiccants. J. Org. Chem. 2010, 75, 8351-8354. [CrossRef] [PubMed]

26. Bellardita, M.; Loddo, V.; Palmisano, G.; Pibiri, I.; Palmisano, L.; Augugliaro, V. Photocatalytic green synthesis of piperonal in aqueous TiO2 suspension. Appl. Catal. B Environ. 2014, 144, 607-613. [CrossRef]

27. Elamathi, P.; Chandrasekar, G.; Muthuraman, S.; Kolli, M.K. Pore size engineering of hexagonal mesoporous carbon nitride $(\mathrm{HMCN})$ for high catalytic performance in the synthesis of $\alpha, \beta$-unsaturated acid and its derivatives. Appl. Surf. Sci. 2019, 463, 481-491. [CrossRef]

28. Schmink, J.R.; Kormos, C.M.; Devine, W.G.; Leadbeater, N.E. Exploring the scope for scale-up of organic chemistry using a large batch microwave reactor. Org. Process. Res. Dev. 2010, 14, 205-214. [CrossRef] 
29. Peng, S.; Zhang, B.; Meng, X.; Yao, J.; Fang, J. Synthesis of piperlongumine analogues and discovery of nuclear factor erythroid 2-related factor 2 (Nrf2) activators as potential neuroprotective agents. J. Med. Chem. 2015, 58, 5242-5255. [CrossRef]

30. Hanwell, M.D.; Curtis, D.E.; Lonie, D.C.; Vandermeersch, T.; Zurek, E.; Hutchison, G.R. Avogadro: An advanced semantic chemical editor, visualization, and analysis platform. J. Cheminform. 2012, 4, 17. [CrossRef]

31. Schmidt, M.W.; Baldridge, K.K.; Boatz, J.A.; Elbert, S.T.; Gordon, M.S.; Jensen, J.H.; Koseki, S.; Matsunaga, N.; Nguyen, K.A.; Su, S. General atomic and molecular electronic structure system. J. Comput. Chem. 1993, 14, 1347-1363. [CrossRef]

32. Gordon, M.S.; Schmidt, M.W. Advances in electronic structure theory: GAMESS a decade later. In Theory and Applications of Computational Chemistry; Elsevier: Amsterdam, The Netherlands, 2005; pp. 1167-1189.

33. Slater, J.C. A simplification of the Hartree-Fock method. Phys. Rev. 1951, 81, 385. [CrossRef]

34. Parr, R.G. Density functional theory of atoms and molecules. In Horizons of Quantum Chemistry; Springer: Boston, MA, USA, 1980; pp. 5-15.

35. Hertwig, R.H.; Koch, W. On the parameterization of the local correlation functional. What is Becke-3-LYP. Chem. Phys. Lett. 1997, 268, 345-351. [CrossRef]

36. Tomasi, J.; Mennucci, B.; Cammi, R. Quantum mechanical continuum solvation models. Chem. Rev. 2005, 105, 2999-3094. [CrossRef] [PubMed]

37. Spackman, M.A. Potential derived charges using a geodesic point selection scheme. J. Comput. Chem. 1996, 17, 1-18. [CrossRef]

38. Bode, B.M.; Gordon, M.S. A graphical user interface for GAMESS. J. Mol. Graph. Model. 1998, 16, $133-138$. [CrossRef]

39. Morris, G.M.; Huey, R.; Lindstrom, W.; Sanner, M.F.; Belew, R.K.; Goodsell, D.S.; Olson, A.J. AutoDock4 and AutoDockTools4: Automated docking with selective receptor flexibility. J. Comput. Chem. 2009, 30, 2785-2791. [CrossRef]

40. Povinelli, A.P.R.; Zazeri, G.; Cornélio, M.L. Molecular Mechanism of Flavonoids Using Fluorescence Spectroscopy and Computational Tools. In Flavonoids-A Coloring Model for Cheering up Life; IntechOpen: London, UK, 2019.

41. Humphrey, W.; Dalke, A.; Schulten, K. VMD: Visual molecular dynamics. J. Mol. Graph. 1996, 14, $33-38$. [CrossRef]

42. Wallace, A.C.; Laskowski, R.A.; Thornton, J.M. LIGPLOT: A program to generate schematic diagrams of protein-ligand interactions. Protein Eng. Des. Sel. 1995, 8, 127-134. [CrossRef]

Sample Availability: Samples of the compounds are available from the authors upon reasonable request.

(C) 2020 by the authors. Licensee MDPI, Basel, Switzerland. This article is an open access article distributed under the terms and conditions of the Creative Commons Attribution (CC BY) license (http://creativecommons.org/licenses/by/4.0/). 